\title{
Terrestrial biogeochemical feedbacks in the climate system
}

\author{
A. Arneth ${ }^{1,2 \star}$, S. P. Harrison ${ }^{3,4}$, S. Zaehle ${ }^{5}$, K. Tsigaridis ${ }^{6,7}$, S. Menon ${ }^{8}$, P. J. Bartlein ${ }^{9}$, J. Feichter ${ }^{10}$, \\ A. Korhola"1, M. Kulmala ${ }^{2}$, D. O'Donnell ${ }^{10}$, G. Schurgers', S. Sorvari ${ }^{2}$ and T. Vesala ${ }^{2}$
}

The terrestrial biosphere is a key regulator of atmospheric chemistry and climate. During past periods of climate change, vegetation cover and interactions between the terrestrial biosphere and atmosphere changed within decades. Modern observations show a similar responsiveness of terrestrial biogeochemistry to anthropogenically forced climate change and air pollution. Although interactions between the carbon cycle and climate have been a central focus, other biogeochemical feedbacks could be as important in modulating future climate change. Total positive radiative forcings resulting from feedbacks between the terrestrial biosphere and the atmosphere are estimated to reach up to 0.9 or $1.5 \mathrm{~W} \mathrm{~m}^{-2} \mathrm{~K}^{-1}$ towards the end of the twenty-first century, depending on the extent to which interactions with the nitrogen cycle stimulate or limit carbon sequestration. This substantially reduces and potentially even eliminates the cooling effect owing to carbon dioxide fertilization of the terrestrial biota. The overall magnitude of the biogeochemical feedbacks could potentially be similar to that of feedbacks in the physical climate system, but there are large uncertainties in the magnitude of individual estimates and in accounting for synergies between these effects.

Research into land-atmosphere exchange processes in climate science has traditionally focused on the surface radiation budget and its effects on sensible and latent heat fluxes, and more recently on carbon-cycle-climate interactions ${ }^{1}$. But many more bidirectional land-atmosphere fluxes modulate atmospheric composition and climate. Biogeochemical feedbacks are intrinsic to the climate system, owing to the nonlinear stimulation of all biological processes by increasing temperatures. Many biogeochemical processes also respond to changes in atmospheric composition and precipitation. Biogeochemical cycles are therefore strongly affected by anthropogenically forced climate change and other human activities ${ }^{2}$.

In this Review we highlight three principal pathways along which biogeochemical cycles interact with the atmosphere and climate. First, climate change alters the biogeochemical cycling of atmospherically well-mixed greenhouse gases, which act directly as radiative forcing agents (Box 1a-c; Supplementary Information). Second, changes in atmospheric composition influence the biogeochemistry of radiatively active compounds (Box 1d). Third, climate change alters the biogeochemistry of substances that are not radiatively active in themselves, but that affect the atmospheric concentration of other climatically active compounds (Box 1e,f). We summarize recent progress in understanding terrestrial biogeochemical feedbacks and their linkages, and provide a first estimate of the potential magnitude of biogeochemical feedbacks associated with human-mediated changes in the biosphere (Fig. 1; Supplementary Information).

Carbon cycling, nitrogen dynamics and greenhouse gases Terrestrial biota acts as a contemporary carbon sink of around 2.8 petagrams $(\mathrm{Pg})$ of carbon annually, thereby restraining the growth rate of atmospheric $\mathrm{CO}_{2}$ from fossil-fuel and land-usechange emissions ${ }^{3}$. The net land-carbon uptake depends on the balance between net primary productivity (NPP) and losses from soil heterotrophic carbon decomposition (Box 1a) and disturbance. The stimulation of photosynthesis by increasing atmospheric $\mathrm{CO}_{2}$ concentrations and lengthening growing seasons exerts a key influence on the future trajectory of the land-carbon sink, but regional reforestation and ecosystem responses to nitrogen deposition also play a role ${ }^{1,4}$. Furthermore, heterotrophic carbon loss is strongly accelerated by enhanced temperatures ${ }^{5}$. As yet, there is no consensus on the relative climate and $\mathrm{CO}_{2}$ trajectories that either NPP or decomposition will follow. But model simulations project a notably reduced carbon sink towards the end of the twenty-first century, with terrestrial processes dominating the global climate feedback ${ }^{4}$. Applying a unifying framework for feedback analyses following Gregory et al. ${ }^{6}$, the average model response yields a further radiative forcing of $0.4 \mathrm{~W} \mathrm{~m}^{-2} \mathrm{~K}^{-1}-$ and up to $0.9 \mathrm{~W} \mathrm{~m}^{-2} \mathrm{~K}^{-1}$ in the most extreme simulation - owing to the reduced carbonsink strength that results from the climate sensitivity of terrestrial processes $^{4,6}$ (Fig. 1; Supplementary Information). These processes substantially reduce the cooling that would be expected from $\mathrm{CO}_{2}$ induced increases in land-carbon uptake in a terrestrial carbon cycle that is insensitive to climatic change.

Carbon is fundamentally linked with other elemental cycles as a result of stoichiometrically determined nutrient requirements for tissue building and decomposition ${ }^{7}$. The availability of nitrogen, which is limited in many ecosystems, plays a critical role in controlling $\mathrm{NPP}^{7,8}$ (Box 1b). In model simulations, nitrogen availability severely constrains the fertilization response of terrestrial carbon assimilation to increasing $\mathrm{CO}_{2}$ concentrations ${ }^{9-11}$

\footnotetext{
'Department of Earth and Ecosystem Science, Lund University, Sölvegatan 12, 22362 Lund, Sweden, ${ }^{2}$ Department of Physics, PO Box 64, Fl-00014, University of Helsinki, Finland, ${ }^{3}$ School of Geographical Sciences, University of Bristol, Bristol BS8 1SS, UK, ${ }^{4}$ School of Biological Sciences, Macquarie University, North Ryde, New South Wales 2109, Australia, ${ }^{5}$ Max Planck Institute for Biogeochemistry, Department of Biogeochemical Systems, Hans Knöll Straße 10, 07745 Jena, Germany, ${ }^{6}$ NASA Goddard Institute for Space Studies, 2880 Broadway, New York 10025, USA, ${ }^{7}$ Center for Climate Systems Research, Columbia University, New York, USA, ${ }^{8}$ LBNL, MS90KR109, 1 Cyclotron Road, Berkeley, California 94720, USA, ${ }^{9}$ Department of Geography, University of Oregon, Eugene, Oregon, USA, ${ }^{10} \mathrm{Max}$ Planck Institute for Meteorology, Hamburg, Germany, "Department of Environmental Sciences, University of Helsinki, PO Box 57, 00014 Helsinki, Finland. *e-mail: Almut.arneth@nateko.lu.se
} 


\section{Box 1 | Important feedback loops linking terrestrial biogeochemical cycles, biosphere-atmosphere exchange, atmospheric composition and climate (here taken as temperature change).}

The main forcings and their effects on biogenic emissions are connected by closed arrows; feedbacks are shown by open arrows. Colours highlight a number of different processes and feedbacks. Only feedbacks to atmospheric composition are shown; further feedbacks from atmospheric composition to temperature are omitted for visual clarity. For the same reason, feedbacks occurring through changes in precipitation or radiation are not plotted. We also omit further interactions that might arise from changes in vegetation type (for example, drying of wetlands, migration of forests, leaf-area index change). a, Increased $\mathrm{CO}_{2}$ concentration fosters terrestrial carbon uptake by enhancing photosynthesis (PS) and NPP. Increased temperature (T) also affects PS and NPP, but
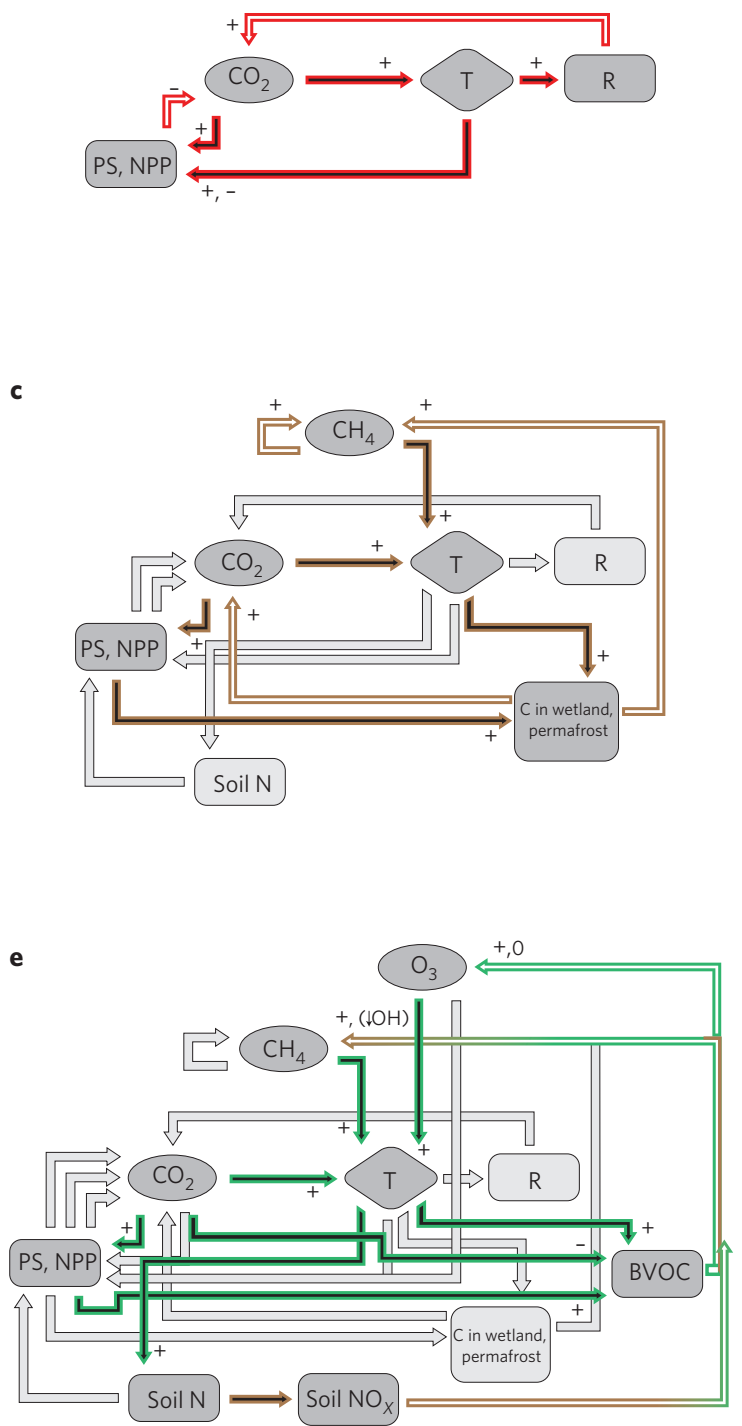

also stimulates ecosystem respiration (R), which has a positive feedback on atmospheric $\mathrm{CO}_{2}$ levels and thus T. b. Warmer T could stimulate soil mineralization, making nitrogen available to sustain terrestrial carbon uptake. c, Elevated T stimulates $\mathrm{CO}_{2}$ and $\mathrm{CH}_{4}$ emissions from global wetlands and northern permafrost soils. d, Increased tropospheric $\mathrm{O}_{3}$ burden from anthropogenic pollution reduces plant photosynthesis owing to its phytotoxic effects. ( $g$ is stomatal conductance.) e, Changed BVOC and soil $\mathrm{NO}_{x}$ emissions in a warmer, high $\mathrm{CO}_{2}$ environment affect trophospheric $\mathrm{O}_{3}$ formation as well as methane lifetime. $\mathbf{f}$, BVOC emissions are the chief precursors for the growth of biogenic secondary aerosols. For further details see Supplementary Information.

b

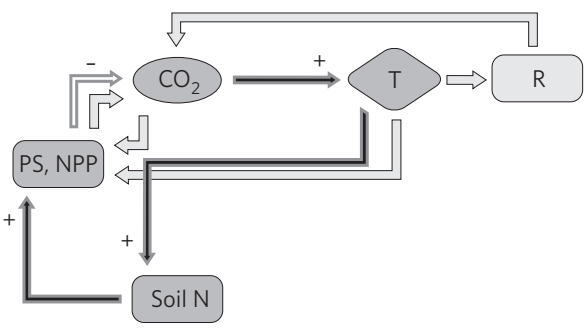

d
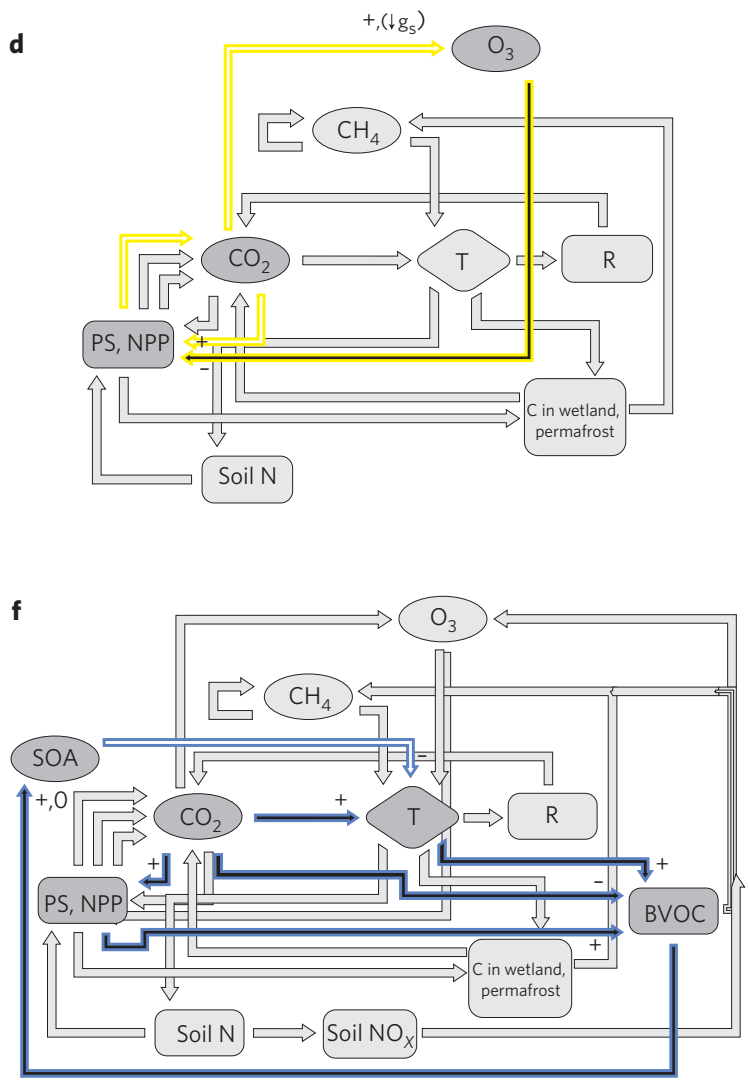

(Fig. $1 ;-0.4$ to -0.8 versus -0.17 to $-1.9 \mathrm{~W} \mathrm{~m}^{-2} \mathrm{~K}^{-1}$ ). However, models with coupled carbon-nitrogen cycles also indicate that warming will enhance soil-nitrogen mineralization, making more nitrogen available to sustain enhanced plant growth $\left(-0.1\right.$ to $\left.0.25 \mathrm{~W} \mathrm{~m}^{-2} \mathrm{~K}^{-1}\right)$. As a result, some coupled models indicate a slight reduction in net carbon loss ${ }^{11}$, whereas others completely remove it ${ }^{9,10}$. Accounting for the synergistic interactions of changing climate, $\mathrm{CO}_{2}$ concentrations and nitrogen deposition, however, consistently results in higher atmospheric $\mathrm{CO}_{2}$ levels in coupled carbon-nitrogen compared with carbon-only simulations, owing 


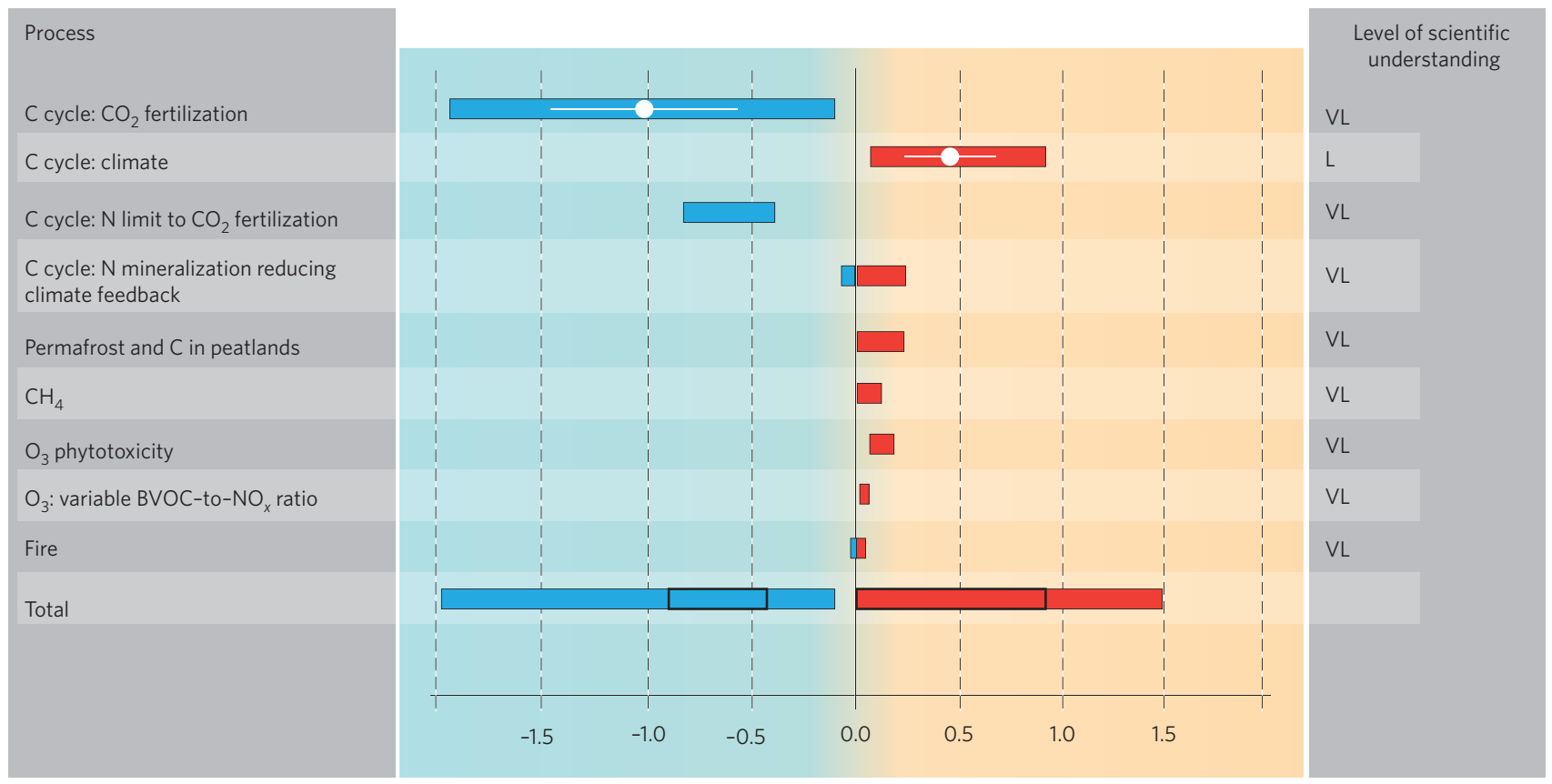

Figure 1 | Radiative forcing from terrestrial biogeochemistry feedbacks in response to anthropogenic atmospheric and climate changes. Bars indicate the approximated minimum-to-maximum feedback range over the twenty-first century. The carbon cycle $\mathrm{CO}_{2}$ and climate feedbacks include average and standard deviations (white). For calculations, adopted from ref. 6, and data sources see Supplementary Information. Totals include top-end estimates, without and with (black rectangle) C-N interactions. Estimates are based on a number of assumptions that had to be made and clearly point to the need for more interdisciplinary studies. Confidence in scientific understanding is at best low (L), in most cases very low (VL).

to the stronger effect of nitrogen limitation on $\mathrm{CO}_{2}$ fertilization ${ }^{10,11}$. This suggests that the rate of climate change is greater than that predicted by carbon-cycle-only models. No study has yet included other nitrogen-cycle climate feedbacks, for example changes in soil emissions of nitrous oxide, the most potent terrestrial greenhouse gas in view of its global warming potential on a time horizon of 20 to 500 years ${ }^{12}$.

The depth of peat attests to the fact that wetlands have been persistent carbon sinks over recent millennia ${ }^{13}$. At the same time, wetland methane $\left(\mathrm{CH}_{4}\right)$ emissions were prominent even in the twentieth-century atmospheric $\mathrm{CH}_{4}$ budget, which was dominated by anthropogenic sources ${ }^{12}$. Anthropogenic climate change is expected to enhance $\mathrm{CH}_{4}$ emissions from wetlands ${ }^{14-16}$, resulting in an estimated further radiative forcing of up to $0.1 \mathrm{~W} \mathrm{~m}^{-2} \mathrm{~K}^{-1}$ at the end of the twentyfirst century (Fig. 1). In high-latitude ecosystems with large peat- and soil-carbon pools ${ }^{17}$ the future net $\mathrm{CO}_{2}$ and $\mathrm{CH}_{4}$ exchange (Box 1c) will depend on the extent of near-surface permafrost thawing ${ }^{18}$, the local thermal versus hydrological regimes ${ }^{19}$ and interactions with the nitrogen cycle ${ }^{20}$. A potential $200 \mathrm{Pg}$ of carbon could be released from combined (global) wetland and permafrost pools by the end of the twenty-first century ${ }^{21}$, equivalent to $\sim 0.24 \mathrm{~W} \mathrm{~m}^{-2} \mathrm{~K}^{-1}$ global forcing if in the form of $\mathrm{CO}_{2}$ (Fig. 1; Supplementary Information). A coupled-model experiment in northern ecosystems estimated a considerably lower feedback, and a loss of only 7 to $17 \mathrm{Pg}$ of carbon owing to permafrost thaw ${ }^{22}$. The extra heat produced during microbial decomposition could accelerate the rate of change in active-layer depth, potentially triggering a sudden and rapid loss of carbon stored in carbon-rich Siberian Pleistocene loess (yedoma) soils ${ }^{23}$. Whether surface ponding will dampen aerobic decomposition sufficiently to provide resistance to fast carbon $\operatorname{loss}^{24}$ is unresolved. In the yedomacase simulation $^{23}$, saturation of the upper metre of soil reduced the annual carbon flux by around $30 \%$, but a total of $180 \mathrm{Pg}$ of carbon was emitted in the form of $\mathrm{CH}_{4}$ by the year 2400 .

\section{Rapidly reactive substances}

As well as influencing atmospheric $\mathrm{CO}_{2}$ and $\mathrm{CH}_{4}$ concentrations, ecosystems exchange substances with the atmosphere that are readily reactive and climatically relevant. Tropospheric ozone $\left(\mathrm{O}_{3}\right)$ is especially important in this context, because of its dual role in affecting, and being strongly affected by, ecosystem processes (Fig. 1; Box 1d,e). Ozone is not only a potent greenhouse gas, narrowly ranked third on the list of forcings for anthropogenic climate change ${ }^{25}$, but is also a strong oxidant, and as such highly toxic to organisms. It enters plants primarily through the stomata. Background and peak levels in industrialized regions -35 to 40 and $>70$ ppb respectively ${ }^{26}$ - reduce plant productivity through direct cellular damage and/or the carbon cost of protection and detoxification. Indeed, $\mathrm{O}_{3}$ phytotoxicity could reduce the global land-carbon sink by 120 to $240 \mathrm{Pg}$ (depending on plant $\mathrm{O}_{3}$ sensitivity) by 2100; the resultant increase in atmospheric $\mathrm{CO}_{2}$ concentrations would exceed the direct radiative forcing associated with increased levels of tropospheric $\mathrm{O}_{3}$ (ref. 27). Using the set of experiments carried out by Sitch et al. ${ }^{27}$, and including the partial protection arising from reduced stomatal conductance in a world rich in $\mathrm{CO}_{2}$, we estimate that the detrimental effects of $\mathrm{O}_{3}$ on carbon uptake could increase radiative forcing by 0.08 to $0.17 \mathrm{~W} \mathrm{~m}^{-2} \mathrm{~K}^{-1}$ by the end of the twenty-first century, in the framework of Gregory et al. ${ }^{6}$ (Fig. 1; Supplementary Information).

Nitrogen oxides $\left(\mathrm{NO}_{x}\right)$ are the chief precursors of tropospheric $\mathrm{O}_{3}$, mainly released during fossil-fuel combustion (around $25 \mathrm{Tg} \mathrm{N} \mathrm{yr}^{-1}$ ) but also with a notable biogenic source ${ }^{28}$ (Box 1e). Global soil $\mathrm{NO}_{x}$ emissions - which recent global inverse-modelling studies place at $>20 \%$ of the total source ${ }^{28}-$ affect $\mathrm{O}_{3}$ chemistry in clean-air environments and provide an important natural source of $\mathrm{O}_{3}$, even in polluted regions. Like all processes linked to soil microbial activity, $\mathrm{NO}_{x}$ emissions are 


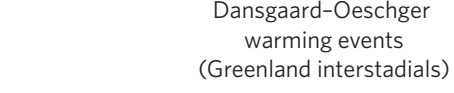

(Greenland interstadials)

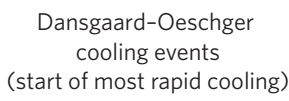

a

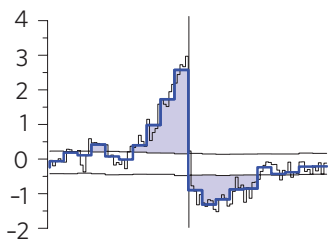

b

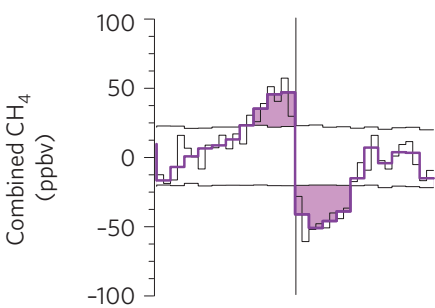

c

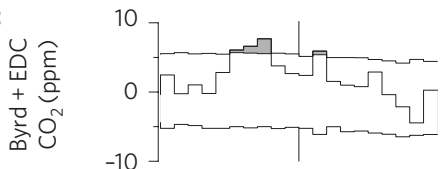

d

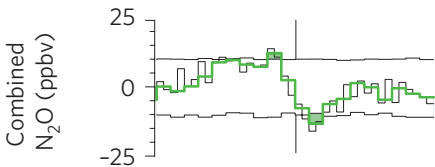

e
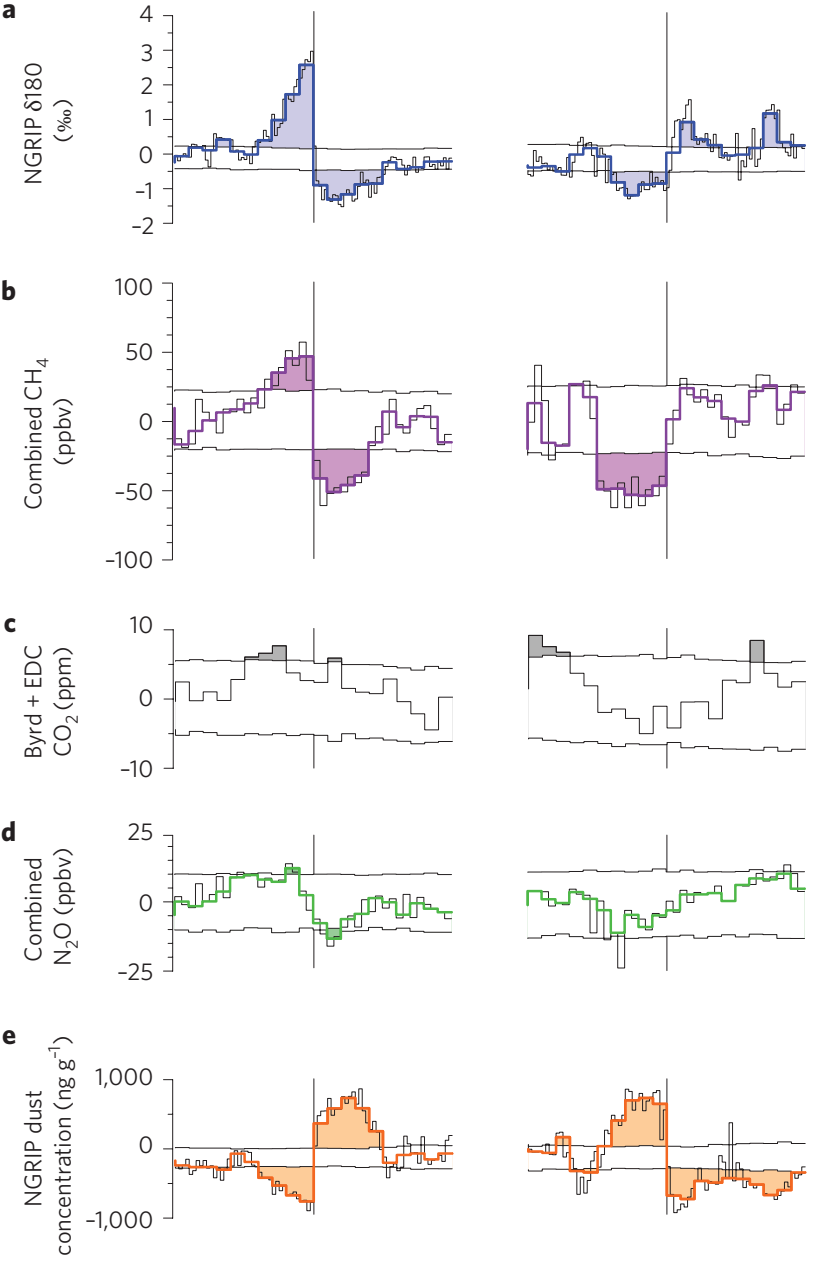

(1)
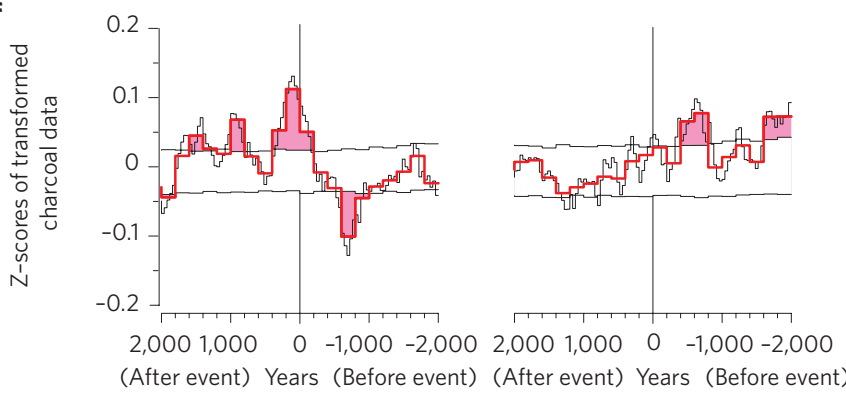

Figure 2 | Superposed epoch analysis of ice-core and biomass-burning records over the interval $80 \mathrm{ka}$ to $10 \mathrm{ka}$. This analysis shows the consistent response of a time series to the repeated occurrence of the abrupt warming and cooling events that define the Dansgaard-Oeschger cycles during the last glacial period. Shading indicates significant patterns in the response of the time series to the events of abrupt warming and rapid cooling. a, The Greenland oxygen-isotope record, an index of regional temperature, shows the characteristic saw-tooth pattern of an individual Dansgaard-Oeschger cycle. b-f, Distinctive responses associated with the occurrence of abrupt warming or cooling. BYRD: Byrd station, Antarctica; EDC: EPICA Dome C; NGRIP: North Greenland Ice Core Project. For data sources and further discussion see Supplementary Information.

sensitive to temperature and moisture, and are directly connected to carbon-nitrogen interactions through plant-litter input and application of fertilizer.
$\mathrm{O}_{3}$ formation also requires the presence of reduced hydrocarbons (Box 1e). Biogenic volatile organic compounds (BVOCs) - which are emitted from live vegetation in a light- and/or temperaturedependent process - constitute a key source of reduced atmospheric hydrocarbons. Isoprene is one of the most important BVOCs. Between 400 and $600 \mathrm{Tg}$ of isoprene are thought to be emitted annually ${ }^{29}$. Model simulations incorporating variable BVOCs, soil and lightning $\mathrm{NO}_{x}$ emissions yield lower pre-industrial $\mathrm{O}_{3}$ levels than previously thought, implying a larger present-day anthropogenic $\mathrm{O}_{3}$ burden of up to $25 \%$ (ref. 30). Estimates in Fig. 1 are for 2100, based on enhanced BVOC emissions in response to warmer temperatures $^{31}$ (Supplementary Information), and disregarding extra effects from $\mathrm{CO}_{2}$ inhibition of BVOC emissions ${ }^{32,33}$. So far, no study has systematically investigated the impact of future global soil $\mathrm{NO}_{x}$ emissions on the $\mathrm{O}_{3}$ burden and associated radiative forcing. Enhanced BVOC emissions also raise uncertainties regarding the lifetime of atmospheric $\mathrm{CH}_{4}$ (ref. 33; Box 1e), because reaction with the hydroxyl radical $(\mathrm{OH})$ is the dominant atmospheric sink for both BVOCs and $\mathrm{CH}_{4}$. The precise $\mathrm{OH}$-reaction mechanisms are under debate at present, and depend on whether these take place in high- $\mathrm{NO}_{x}$ (polluted) or low- $\mathrm{NO}_{x}$ (non-polluted) environments ${ }^{34,35}$. A process-based understanding of present-day and future source distributions of BVOCs and $\mathrm{NO}_{x}$ is therefore needed to constrain estimates of $\mathrm{CH}_{4}$ and $\mathrm{O}_{3}$ radiative forcing.

\section{From gases to particles}

The influence of aerosol particles on climate, and how their properties are perturbed by anthropogenic activity, is one of the key uncertainties in climate change assessments ${ }^{12}$. Black-carbon aerosols, which absorb in the visible spectrum, exert a strong positive forcing that is enhanced by snow-albedo changes owing to soot deposition. Black carbon has been proposed to increase radiative forcing by a maximum of $\sim 0.9 \mathrm{~W} \mathrm{~m}^{-2}$ globally, which is larger than the forcing associated with $\mathrm{CH}_{4}$, and is $55 \%$ of that associated with $\mathrm{CO}_{2}$ (ref. 36). However, other studies suggest a lower average black-carbon forcing ${ }^{12}$. In contrast, mostly scattering aerosols such as sulphate, organic carbon and nitrate produce a negative direct forcing ${ }^{12,37}$. Increases in black carbon and concomitant reductions in sulphate pollution were estimated to have contributed $\sim 70 \%$ of the observed warming in the Arctic ${ }^{38}$. Indirect aerosol effects on cloud microphysics, lifetime and precipitation rate are associated with large, poorly constrained climate uncertainties ${ }^{39,40}$.

Terpenoid BVOC emissions and their oxidation products are the largest global source of secondary organic aerosols (SOA) (Box 1f $)^{41}$. The direct contribution of anthropogenic emissions to SOA is small, but anthropogenic aerosols may serve as nuclei for biogenic SOA formation and growth ${ }^{42}$. Recent work has shown that monoterpenes are the chief determinant of aerosol mass over boreal forests ${ }^{43}$, and that sesquiterpene oxidation products are crucial for the initial stages of particle formation ${ }^{44}$. The situation with isoprene is more complex: it has been recognized as an SOA precursor ${ }^{45,35}$, but isoprene has also been shown to suppress particle formation from monoterpenes, probably through competing reactions with $\mathrm{OH}$ (ref. 46). Links between enhanced BVOC emissions, accelerated SOA production and larger SOA burden in a warmer climate are one of only a few biosphere-atmosphere feedbacks that could result in a cooling, through the direct aerosol effect or changes in cloud albedo ${ }^{40,47}$.

No study so far has investigated the effects of changes in global biogenic emissions on radiative forcing in future-warming experiments. For present-day conditions, O'Donnell et al. ${ }^{48}$ estimated the shortwave radiative effect of SOA, which originate mostly from biogenic precursors, in terms of differences with and without them. The annual mean direct effect was modelled as $-0.3 \mathrm{~W} \mathrm{~m}^{-2}$. This effect was mitigated by a positive cloud-albedo effect in polluted areas, 
amounting to more than $+0.2 \mathrm{~W} \mathrm{~m}^{-2}$ in the global mean, a result that is so far unique to this model (Supplementary Information). $\mathrm{K}$. Tsigaridis and S. Menon (unpublished data) determined direct radiative forcing of SOA based on differences between present-day and pre-industrial aerosol loadings; applying notably lower BVOC emissions in their study, they estimate a direct SOA-induced forcing of $-0.02 \mathrm{~W} \mathrm{~m}^{-2}$, compared with a total aerosol direct forcing of $-0.21 \mathrm{~W} \mathrm{~m}^{-2}$.

Allowing for the sensitive response of BVOC leaf emissions to warmer temperatures, SOA production is estimated to increase substantially in a future warmer climate ${ }^{49,50}$. It is as yet unknown whether processes leading to direct $\mathrm{CO}_{2}$ inhibition of isoprene production ${ }^{33}$ also affect production of monoterpenes or sesquiterpenes, their release from storage pools, and hence future SOA burden and radiative forcing. Monoterpene metabolic production, located in the chloroplast, is rather similar to that of isoprene. Recent studies indicate reduced production and needle-tissue levels of monoterpenes in Douglas firs grown at elevated $\mathrm{CO}_{2}$ levels ${ }^{51}$. Whether or not the interactive effects of temperature, photosynthetically active radiation and $\mathrm{CO}_{2}$ (ref. 52) will indeed lead to a strong increase in terpenoid emissions is so far unresolved.

\section{Up in smoke}

Fire is a natural, regularly recurring episodic event across all vegetated biomes, most prominent in savannas and Mediterranean or boreal forest ecosystems ${ }^{53}$. In the absence of transient changes in fire regimes caused by climate or land-use change, fires have little effect on the average annual net carbon balance because the carbon released is rapidly recaptured by regrowing vegetation. However, fires act on the carbon cycle by accelerating both primary production and respiration, and fire patterns have a strong influence on the interannual variation in the atmospheric growth rates of $\mathrm{CO}_{2}$ and $\mathrm{CH}_{4}$ (ref. 53). Large atmospheric impacts of fire are related to emissions of particles, $\mathrm{O}_{3}, \mathrm{CH}_{4}$ and other volatile hydrocarbons, either directly or as their precursors ${ }^{53}$. Global biomass burning represents between around 15 to $40 \%$ of the global $\mathrm{NO}_{x}$ and $\mathrm{CO}$ emissions, respectively ${ }^{28,54}$. Model simulations suggest that radiative forcing is highly sensitive to variations in overall pyrogenic emissions ${ }^{5-56}$. Although net effects may be small (Fig. 1), a change in burn conditions could easily shift fire-related forcing in either direction.

\section{Past links between biogeochemical cycles and climate}

Ice-core records reveal that the atmospheric composition of greenhouse gases and mineral-dust aerosol has covaried with rapid and gradual changes in climate, over at least the past 800,000 years $^{57-59}$, with the phasing of changes in individual greenhouse gases modulated by differences in the temporal and spatial patterning of (ocean and terrestrial) biospheric feedbacks (Fig. 2; also see ref. 60 for example). Substantial glacial-interglacial vegetation changes are documented in pollen and plant-macrofossil records ${ }^{61}$. Vegetation types adapted to low $\mathrm{CO}_{2}$ levels, drought and cool temperatures were wide-spread at the Last Glacial Maximum, whereas orbitally induced insolation changes during the first part of the Holocene resulted in high-latitude warming that led to northward expansion of boreal and temperate forests, and enhanced monsoons that caused northward expansion of Sahelian vegetation ${ }^{62}$. These large-scale changes in turn led to changes in dust emission ${ }^{63}$ and fire regimes ${ }^{64}$. Pollen and charcoal data have also demonstrated extremely rapid responses to climate variability such as DansgaardOeschger events (rapid climate events that occurred during the last glacial period) or the onset/termination of the Younger Dryas ${ }^{65}$. The palaeorecord thus points not only to a number of terrestrial biogeophysical feedbacks ${ }^{66-68}$, but also to substantial impacts of biogeochemical cycling on atmospheric composition and climate.
For example, peatland productivity and decomposition are highly sensitive to temperature and precipitation changes, hence their carbon sequestration varies on decadal to millennial timescales. These changes in sequestration in turn feed back to atmospheric composition. Peatland initiation in the northern high latitudes began around 15,000 years ago, during the deglaciation. Almost half of the modern peatland began to form before 8,000 years ago $^{69}$; around $100 \mathrm{Pg}$ of carbon were sequestered in the process, contributing to the observed drawdown of atmospheric $\mathrm{CO}_{2}$ and the peak in atmospheric $\mathrm{CH}_{4}$ in the early Holocene $\mathrm{e}^{70}$. Increased peat-accumulation rates are registered during the warmer conditions of the early to mid-Holocene in the northern high latitudes ${ }^{71}$, whereas substantially reduced accumulation occurred during the cold intervals of the Younger Dryas and the Little Ice $\mathrm{Age}^{72}$. The most extensive lateral expansion of high-latitude peatlands occurred only after 5,000 years ago $^{73}$, coinciding with the late-Holocene increase in $\mathrm{CH}_{4}$ shown by ice-core records. The overall climate impact of changes in peat accumulation is uncertain because of the competing influences of $\mathrm{CO}_{2}$ carbon sequestration and $\mathrm{CH}_{4}$ emissions. Frolking et al. ${ }^{74}$ have suggested that the initial impact of northern peatland growth is a net warming that peaks about 50 years after peatland initiation, but remains positive for the next several hundred to thousand years, depending on the rate of carbon sequestration, although after this peatlands would have an ever-increasing net cooling impact. However, these calculations were made without taking into account the impact of climate variability on peatland growth, carbon uptake and $\mathrm{CH}_{4}$ emissions.

Analyses of interhemispheric gradients of ice-core $\mathrm{CH}_{4}$ concentrations and carbon isotope composition have been interpreted as indicating that changes in wetland emissions drove glacial-interglacial $\mathrm{CH}_{4}$ changes ${ }^{75,76}$. However, simulations using simple formulations of wetland extent and emissions have been unable to reduce wetland sources sufficiently to produce the low levels of glacial atmospheric $\mathrm{CH}_{4}$ concentrations ${ }^{77,78}$. Alternatively, as $\mathrm{OH}$ is the chief atmospheric sink for both $\mathrm{CH}_{4}$ and BVOCs, it has been suggested that strongly reduced BVOC emissions during the Last Glacial Maximum, in response to cooler temperatures and less-productive vegetation, led to increased $\mathrm{OH}$ levels, decreasing the lifetime and concentration of $\mathrm{CH}_{4}$ (ref. 77). Yet, these model experiments disregard the suggestion that BVOC emissions under low atmospheric $\mathrm{CO}_{2}$ levels may have been more conservative ${ }^{32}$ than assumed in this simulation.

The palaeorecord of changes in fire regime provides a second example of biogeochemistry-atmosphere-climate feedbacks. Global compilations of charcoal in continuously deposited lake or bog sediments show less fire during glacial than interglacial intervals ${ }^{64}$, as a consequence of the reduction in biosphere productivity and hence fuel availability that occurs as a result both of cold, dry glacial climates, and the direct impact of low levels of $\mathrm{CO}_{2}$ on plant productivity. On centennial to millennial timescales, fire activity covaries with climate change $^{79}$ - indeed, biomass burning declined towards the Little Ice Age - supporting the interpretation by Ferretti et al. ${ }^{80}$ of the icecore record of changes in ${ }^{13} \mathrm{CH}_{4}$ as a reflection of changes in biomass burning. Fire regimes show a large response to both rapid warming and rapid cooling ${ }^{81,82}$; during the last glacial period, for example, fire regimes tracked Dansgaard-Oeschger warming events with lag times on the order of a few decades (Fig. 2); the lag in response to the cooling associated with Heinrich stadials was slightly longer ${ }^{81}$.

\section{Detecting the signal from the noise}

Remotely sensed vegetation greening ${ }^{83}$, and ground-based evidence for vegetation changes in northern latitudes that have experienced amplified warming, demonstrate the responsiveness of terrestrial biota to trends in climate, with corresponding changes in biogeochemical cycling ${ }^{84}$. The interannual variation in the atmospheric $\mathrm{CO}_{2}$ growth rate is dominated by interactions between the terrestrial carbon cycle, climate and fire ${ }^{83,85,86}$. Inversions of atmospheric 
concentration measurements suggest that wetland and, to a lesser extent, fire emissions have dominated the interannual variability in $\mathrm{CH}_{4}$ growth rate during the past few decades ${ }^{87}$. Interannual variation in atmospheric $\mathrm{CO}, \mathrm{CO}_{2}$ and its isotopic ratios are related to variability in climate-fire emissions from boreal or tropical regions, for example in response to precipitation pattern $\mathrm{s}^{53,88}$, and further feedbacks exist between increased post-burn surface temperature and substantially reduced vegetation productivity ${ }^{89}$. In unpolluted tropical forests, atmospheric $\mathrm{OH}$ levels are remarkably stable even when BVOC emissions are high, although such emissions were thought to dampen the atmospheric oxidation capacity ${ }^{34}$. The multitude of processes that need to be considered makes it close to impossible to detect actual system feedback responses with present observations. But the observational evidence supports the view of tight connections between climate, vegetation and biogeochemical cycling both in terms of greenhouse gas exchange and of atmospheric-reactivityclimate interactions.

\section{Land cover and biogeochemical cycling}

Our focus on the interactions between climate, atmospheric composition and biogeochemical cycles should not detract attention from changes in natural vegetation cover, and those in anthropogenic land use and land cover, as the main influences on surface-atmosphere exchange and feedbacks ${ }^{90,91}$. There are large uncertainties in the estimates of radiative forcing resulting from changes in surface albedo, and the energy balance associated with historic land-cover change ${ }^{92,93}$. Deforestation, particularly by fire, releases a large amount of carbon into the atmosphere that is not returned into the terrestrial system when forests are replaced by agricultural systems ${ }^{53}$. The BVOC emission spectra of forests and agricultural systems are very different ${ }^{94}$; the former dominated by terpenoids - which are prime precursors of SOA and $\mathrm{O}_{3}$ - the latter dominated by oxygenated BVOCs, with different but poorly understood atmospheric chemistry. In-canopy reactions of soil $\mathrm{NO}_{x}$ emissions also differ between forests and crops, with escape into the atmosphere being much larger in short canopies ${ }^{28}$. Moreover, fertilization and irrigation of agricultural systems provide an overriding cause for altered carbonnitrogen cycling and reactive emissions of nitrogen-containing trace gases ${ }^{8}$. Existing experimental observations and simulations are insufficient to provide a quantitative synthesis of the impacts of land-cover changes; field and model experiments addressing this must be a future research priority ${ }^{95}$.

\section{What's in a global number?}

There is growing evidence that the impact of biogeochemical feedbacks must not be ignored in climate change studies. For simplicity, in this Review we assume that individual effects add up, with maxima depending on the extent to which nitrogen limits or stimulates carbon sequestration. According to our analysis, the combined estimated positive forcing from feedbacks associated with carbon, nitrogen and atmospheric chemistry in response to anthropogenic warming could further increase warming. Indeed, biogeochemical positive forcing could potentially cancel out cooling associated with $\mathrm{CO}_{2}$ fertilization of the biosphere, an effect that has been proposed to mitigate warming (Fig. 1). SOA formation could also act to cool the climate, but at least for present-day simulations, the relative magnitude of the direct and indirect effects depends strongly on assumptions in SOA models. Given the limited number of quantitative experiments available, our estimates of the total radiative forcing from biogeochemical feedbacks that operate in the climatechemistry system can only serve as a very rough guide. Nonetheless, we conclude that the climate effect of changes in element cycles and atmospheric chemistry is comparable in magnitude to that of physical feedbacks such as water vapour or clouds ${ }^{96}$.

The path from a change in emissions to a change in radiative forcing, and henceforward to a change in climate, is convoluted, particularly for heterogeneously mixed reactive substances in the atmosphere. Each of these changes has its own geographically varied pattern, and, when overlain, these patterns generally do not match $^{97}$. Chemical reactions of a trace gas depend on the degree of pollution, temperature and humidity; chemistry-climate interactions are also affected by long-range transport of emission reaction products. A small change in the global burden of a given substance can hide substantial regional variability, thus averaging over positive or negative changes in local radiative forcing ${ }^{33,38}$. Here, we have summarized the interactions of biogeochemical cycles with the climate system in terms of global forcing feedbacks, by analogy to the global radiative forcing estimates generated by the IPCC. But we stress the need for the development of a more refined metric ${ }^{98}$, and for the consideration not only of radiative effects, but also of other important ecosystem functions ${ }^{99}$.

Because our understanding of the processes is limited, it has been necessary to focus on individual biogeochemical feedbacks. However, the intricate coupling of terrestrial biogeochemical cycles of inert greenhouse gases with reactive atmospheric chemistry means that none of the feedbacks summarized here will act in isolation. At present we have to ignore nonlinearities, and thus possible thresholds in the system, to make simulations with ecosystemchemistry-climate models feasible. But improved understanding of biogeochemical cycle interactions should be a priority for the scientific community. This will aid development and implementation of atmosphere and ecosystem management, particularly in light of post-Kyoto negotiations ${ }^{100}$, and the development of climate and airpollution control strategies.

\section{References}

1. Heimann, M. \& Reichstein, M. Terrestrial ecosystem carbon dynamics and climate feedbacks. Nature 451, 289-292 (2008).

2. Rosenzweig, C. et al. Attributing physical and biological impacts to anthropogenic climate change. Nature 453, 353-357 (2008).

3. Canadell, J. G. et al. Contributions to accelerating atmospheric $\mathrm{CO}_{2}$ growth from economic activity, carbon intensity, and efficiency of natural sinks. Proc. Natl Acad. Sci. USA 104, 18866-18870 (2007).

4. Friedlingstein, P. et al. Climate-carbon cycle feedback analysis: Results from the (CMIP)-M-4 model intercomparison. J. Clim. 19, 3337-3353 (2006).

5. Davidson, E. A. \& Janssens, I. A. Temperature sensitivity of soil carbon decomposition and feedbacks to climate change. Nature 440, 165-173 (2006).

6. Gregory, J. M., Jones, C. D., Cadule, P. \& Friedlingstein, P. Quantifying carbon cycle feedbacks. J. Clim. 22, 5232-5250 (2009).

7. Vitousek, P., Hättenschwiler, S., Olander, L. \& Allison, S. Nitrogen and Nature. Ambio 31, 97-102 (2002).

8. Gruber, N. \& Galloway, J. N. An Earth-system perspective of the global nitrogen cycle. Nature 451, 293-296 (2008).

9. Thornton, P. E. et al. Carbon-nitrogen interactions regulate climate-carbon cycle feedbacks: results from an atmosphere-ocean general circulation model. Biogeosciences 6, 2099-2120 (2009).

10. Sokolov, A. P. et al. Consequences of considering carbon-nitrogen interactions on the feedbacks between climate and the terrestrial carbon cycle. J. Clim. 21, 3776-3796 (2008).

11. Zaehle, S., Friedlingstein, P. \& Friend, A. D. Terrestrial nitrogen feedbacks may accelerate future climate change. Geoph. Res. Lett. 37, L01401 (2010).

12. Forster, P. et al. in Climate Change 2007: The Physical Science Basis. (eds Solomon, S. et al.) 130-234 (Cambridge Univ. Press, 2007).

13. Frolking, S. \& Roulet, N. T. Holocene radiative forcing impact of northern peatland carbon accumulation and methane emissions. Glob. Change Biol. 13, 1079-1088 (2007).

14. Gedney, N., Cox, P. M. \& Huntingford, C. Climate feedback from wetland methane emissions. Geophys. Res. Lett. 31, L20503 (2004).

15. Eliseev, A. V., Mokhov, I. I., Arzhanov, M. M., Demchenko, P. F. \& Denisov, S. N. Interaction of the methane cycle and processes in wetland ecosystems in a climate model of intermediate complexity. Izv. Atmos. Ocean. Phys. 44, 139-152 (2008).

16. Volodin, E. M. Methane cycle in the INM RAS climate model. Izv. Atmos. Ocean. Phys. 44, 153-159 (2008).

17. Tarnocai, C. et al. Soil organic carbon pools in the northern circumpolar permafrost region. Glob. Biogeochem. Cycles 23, GB2023 (2009).

18. Lawrence, D. M. \& Slater, A. G. A projection of severe near-surface permafrost degradation during the 21st century. Geophys. Res. Lett. 32, L24401 (2005). 
19. Walter, K. M., Zimov, S. A., Chanton, J. P., Verbyla, D. \& Chapin, F. S. Methane bubbling from Siberian thaw lakes as a positive feedback to climate warming. Nature 443, 71 (2006).

20. Bragazza, L. et al. Atmospheric nitrogen deposition promotes carbon loss from peat bogs. Proc. Natl Acad. Sci. USA 103, 19386-19389 (2006).

21. Gruber, N. et al. in The Global Carbon Cycle: Integrating Humans, Climate, and the Natural World (eds Field, C. \& Raupach, M. R.) 45-76 (Island, 2004).

22. Zhuang, Q. et al. $\mathrm{CO}_{2}$ and $\mathrm{CH}_{4}$ exchanges between land ecosystems and the atmosphere in northern high latitudes over the 21 st century. Geophys. Res. Lett. 33, L17403 (2006).

23. Khvorostyanov, D. V., Ciais, P., Krinner, G. \& Zimov, S. A. Vulnerability of east Siberia's frozen carbon stores to future warming. Geophys. Res. Lett. 35, L10703 (2008)

24. Ise, T., Dunn, A. L., Wofsy, S. C. \& Moorcroft, P. R. High sensitivity of peat decomposition to climate change through water-table feedback. Nature Geosci. 1, 763-766 (2008)

25. Denman, K. L. et al. in Climate Change 2007: The Physical Science Basis (eds Solomon, S. et al.) 499-587 (Cambridge Univ. Press, 2007).

26. Ashmore, M. R. Assessing the future global impacts of ozone on vegetation. Plant Cell Environ. 28, 949-964 (2005).

27. Sitch, S., Cox, P. M., Collins, W. J. \& Huntingford, C. Indirect radiative forcing of climate change through ozone effects on the land-carbon sink. Nature 448, 791-794 (2007).

28. Jaegle, L., Steinberger, L., Martin, R. V. \& Chance, K. Global partitioning of $\mathrm{NO}_{\mathrm{x}}$ sources using satellite observations: Relative roles of fossil fuel combustion, biomass burning and soil emissions. Faraday Discuss. 130, 407-423 (2005).

29. Arneth, A., Monson, R. K., Schurgers, G., Niinemets, U. \& Palmer, P. I. Why are estimates of global isoprene emissions so similar (and why is this not so for monoterpenes)? Atm. Chem. Phys. 8, 4605-4620 (2008).

30. Mickley, L. J., Jacob, D. \& Rind, D. Uncertainty in preindustrial abundance of tropospheric ozone: Implications for radiative forcing calculations. J. Geophys. Res. 106, 3389-3399 (2001).

31. Hauglustaine, D. A., Lathiere, J., Szopa, S. \& Folberth, G. A. Future tropospheric ozone simulated with a climate-chemistry-biosphere model. Geophys. Res. Lett. 32, L24807 (2005).

32. Arneth, A. et al. $\mathrm{CO}_{2}$ inhibition of global terrestrial isoprene emissions: Potential implications for atmospheric chemistry. Geophys. Res. Lett. 34, L18813 (2007)

33. Young, P. J., Arneth, A., Schurgers, G., Zeng, G. \& Pyle, J. The $\mathrm{CO}_{2}$ inhibition of terrestrial isoprene emission significantly affects future ozone projections. Atm. Chem. Phys. 9, 2793-2803 (2009).

34. Lelieveld, J. et al. Atmospheric oxidation capacity sustained by a tropical forest. Nature 452, 737-740 (2008).

35. Paulot, F. et al. Unexpected epoxide formation in the gas-phase photooxidation of isoprene. Science 325, 730-733 (2009).

36. Ramanathan, V. \& Carmichael, G. Global and regional climate changes due to black carbon. Nature Geosci. 1, 221-227 (2008).

37. Andreae, M. O. Atmospheric aerosols versus greenhouse gases in the twentyfirst century. Phil. Trans. R. Soc. A 365, 1915-1923 (2007).

38. Shindell, D. \& Faluvegi, G. Climate response to regional radiative forcing during the twentieth century. Nature Geosci. 2, 294-300 (2009).

39. Rosenfeld, D. et al. Flood or drought: how do aerosols affect precipitation? Science 321, 1309-1313 (2008).

40. Carslaw, K. S. et al. A review of natural aerosol interactions and feedbacks within the Earth system. Atmos. Chem. Phys. 10, 1701-1737 (2010).

41. Hallquist, M. et al. The formation, properties and impact of secondary organic aerosol: current and emerging issues. Atm. Chem. Phys. 9, 5155-5235 (2009).

42. Kanakidou, M., Tsigaridis, K., Dentener, F. J. \& Crutzen, P. J. Human-activityenhanced formation of organic aerosols by biogenic hydrocarbon oxidation. J. Geophys. Res. 105, 9243-9254 (2000).

43. Tunved, P. et al. High natural aerosol loading over boreal forests. Science 312, 261-263 (2006).

44. Bonn, B. \& Moortgat, G. K. Sesquiterpene ozonolysis: Origin of atmospheric new particle formation from biogenic hydrocarbons. Geophys. Res. Lett. 30, 1585 (2003).

45. Claeys, M. et al. Formation of secondary organic aerosols through photooxidation of isoprene. Science 303, 1173-1176 (2004).

46. Kiendler-Scharr, A. et al. New particle formation in forests inhibited by isoprene emissions. Nature 461, 381-384 (2009).

47. Kulmala, M. et al. A new feedback mechanism linking forests, aerosols, and climate. Atm. Chem. Phys. 4, 557-562 (2004)

48. O'Donnell, D. Towards the Assessment of the Climate Effects of Secondary Organics Aerosols PhD thesis, Univ. Hamburg (2010).

49. Tsigaridis, K. \& Kanakidou, M. Secondary organic aerosol importance in the future atmosphere. Atm. Env. 41, 4682-4692 (2007).
50. Heald, C. L. et al. Predicted change in global secondary organic aerosol concentrations in response to future climate, emissions, and land use change. J. Geophys. Res. 113, D05211 (2008).

51. Snow, M. D. et al. Monoterpene levels in needles of Douglas fir exposed to elevated $\mathrm{CO}_{2}$ and temperature. Physiol. Plantarum 117, 352-358 (2003).

52. Schurgers, G., Arneth, A., Holzinger, R. \& Goldstein, A. H. Process-based modelling of biogenic monoterpene emissions: sensitivity to temperature and light. Atm. Chem. Phys. 9, 3409-3423 (2009)

53. Bowman, D. M. J. S. et al. Fire in the Earth System. Science 324, 481-484 (2009).

54. Bian, H. et al. Sensitivity of global CO simulations to uncertainties in biomass burning sources. J. Geophys. Res. 112, D23308 (2007).

55. Naik, V. et al. On the sensitivity of radiative forcing from biomass burning aerosols and ozone to emission location. Geophys. Res. Lett. 34, L03818 (2007)

56. Ito, A., Sudo, K., Akimoto, H., Sillman, S. \& Penner, J. Global modeling analysis of tropospheric ozone and its radiative forcing from biomass burning emissions in the twentieth century. J. Geophys. Res. 112, D24307 (2007).

57. Loulergue, L. et al. Orbital and millennial-scale features of atmospheric $\mathrm{CH}_{4}$ over the past 800,000 years. Nature 453, 383-386 (2008).

58. Lambert, F. et al. Dust-climate couplings over the past 800,000 years from the EPICA Dome C ice core. Nature 452, 616-619 (2008).

59. Luthi, D. et al. High-resolution carbon dioxide concentration record 650,000800,000 years before present. Nature 453, 379-382 (2008).

60. Jansen, E. et al. in Climate Change 2007: The Physical Science Basis (eds Solomon, S. et al.) 433-497 (Cambridge Univ. Press, 2007).

61. Gajewski, K. The Global Pollen Database in biogeographical and palaeoclimatic studies. Prog. Phys. Geogr. 32, 379-402 (2008).

62. Prentice, I. C., Jolly, D. \& BIOME 6000 Participants. Mid-Holocene and glacial-maximum vegetation geography of the northern continents and Africa. J. Biogeo. 27, 507-519 (2000).

63. Kohfeld, K. E. \& Harrison, S. P. DIRTMAP: the geological record of dust. Earth Sci. Rev. 65, 81-114 (2001).

64. Power, M. J. et al. Changes in fire regimes since the Last Glacial Maximum: an assessment based on a global synthesis and analysis of charcoal data. Clim. Dyn. 30, 887-907 (2008)

65. Tzedakis, P. C. Towards an understanding of the response of southern European vegetation to orbital and suborbital climate variability. Quat. Sci. Rev. 24, 1585-1599 (2005).

66. Jahn, A., Claussen, M., Ganopolski, A. \& Brovkin, V. Quantifying the effect of vegetation dynamics on the climate of the last glacial maximum. Clim. Past 1, 1-7 (2005).

67. Claussen, M. \& Gayler, V. The greening of the Sahara during the midHolocene: Results of an interactive atmosphere-biome model. Quat. Sci. Rev. 6, 369-377 (1997)

68. Braconnot, P. et al. Results of PMIP2 coupled simulations of the mid-Holocene and Last Glacial Maximum, Part 2: feedbacks with emphasis on the location of the ITCZ and mid- and high latitudes heat budget. Clim. Past 3, 279-296 (2007)

69. MacDonald, G. M. et al. Rapid early development of circumarctic peatlands and atmospheric $\mathrm{CH}_{4}$ and $\mathrm{CO}_{2}$ variations. Science 314, 285-288 (2006)

70. Yu, Z., Beilman, D. W. \& Jones, M. C. in Geophy. Monog. Series (eds Baird, A. J. et al.) (AGU, 2009).

71. Kaufman, D. S. et al. Holocene thermal maximum in the western Arctic (0-180 ${ }^{\circ}$ W). Quat. Sci. Rev. 23, 529-560 (2004).

72. Oldfield, F. et al. Radiocarbon dating of a recent high-latitude peat profile: Stor Amyran, northern Sweden. Holocene 7, 283-290 (1997).

73. Korhola, A. et al. The importance of northern peatland expansion to the LateHolocene rise of atmospheric methane. Quat. Sci. Rev. 29, 611-617 (2010)

74. Frolking, S., Roulet, N. \& Fuglestvedt, J. How northern peatlands influence the Earth's radiative budget: Sustained methane emission versus sustained carbon sequestration. J. Geophys. Res. 111, G01008 (2006).

75. Martinerie, P., Brasseur, G. P. \& Granier, C. The chemical composition of ancient atmospheres: A model study constrained by ice core data. J. Geophys. Res. 100, 14291-14304 (1995).

76. Schaefer, H. et al. Ice record of $\mathrm{d} 13 \mathrm{C}$ for atmospheric $\mathrm{CH}_{4}$ across the Younger Dryas-Preboreal transition. Science 313, 1109-1112 (2006).

77. Kaplan, J. O., Folberth, G. \& Hauglustaine, D. A. Role of methane and biogenic volatile organic compound sources in late glacial and Holocene fluctuations of atmospheric methane concentrations. Glob. Biogeochem. Cycles 20, GB2016 (2006).

78. Valdes, P. J., Beerling, D. J. \& Johnson, D. E. The ice age methane budget. Geophys. Res. Lett. 32, L02704 (2005).

79. Marlon, J. R. et al. Climate and human influences on global biomass burning over the past two millennia. Nature Geosci. 1, 697-702 (2008).

80. Ferretti, D. F. et al. Unexpected changes to the global methane budget over the past 2000 years. Science 309, 1714-1717 (2005).

81. Daniau, A-L., Harrison, S. P. \& Bartlein, P. J. Fire regimes during the last glacial. Quat. Sci. Rev. doi:10.1016/j.quascirev.2009.1011.1008 (2010). 
82. Marlon, J. R. et al. Wildfire responses to abrupt climate change in North America. Proc. Natl Acad. Sci. USA 106, 2519-2524 (2009).

83. Lucht, W. et al. Climatic control of the high-latitude vegetation greening trend and Pinatubo effect. Science 296, 1687-1689 (2002).

84. Christensen, T. R., Johansson, T., Åkerman, H. J. \& Mastepanov, M. Thawing sub-arctic permafrost: Effects on vegetation and methane emissions. Geophys. Res. Lett. 31, L04501 (2004).

85. Peylin, P. et al. Multiple constraints on regional $\mathrm{CO}_{2}$ flux variations over land and oceans. Glob. Biogeochem. Cycles 19, GB1011 (2005).

86. Randerson, J. R., Thompson, M. V., Conway, T. J., Fung, I. \& Field, C. B. The contribution of terrestrial sources and sinks to trends in the seasonal cycle of atmospheric carbon dioxide. Glob. Biogeochem. Cycles 11, 535-560 (1997).

87. Bousquet, P. et al. Contribution of anthropogenic and natural sources to atmospheric methane variability. Nature 443, 439-443 (2006).

88. Langmann, B., Duncan, B., Textor, C., Trentmann, J. \& van der Werf, G. R. Vegetation fire emissions and their impact on air pollution and climate. Atmos. Env. 43, 107-116 (2009).

89. Running, S. W. Ecosystem disturbance, carbon, and climate. Science 321, 652-653 (2008).

90. Jones, C., Lowe, J., Liddicoat, S. \& Betts, R. Committed terrestrial ecosystem changes due to climate change. Nature Geosci. 2, 484-487 (2009).

91. Bonan, G. B. Forests and climate change: Forcings, feedbacks, and the climate benefits of forests. Science 320, 1444-1449 (2008).

92. Betts, R. A. Offset of the potential carbon sink from boreal forestation by decreases in surface albedo. Nature 408, 187-190 (2000).

93. Pitman, A. J. et al. Uncertainties in climate responses to past land cover change: First results from the LUCID intercomparison study. Geophys. Res. Lett. 36, L14814 (2009).

94. Lathière, J. et al. Impact of climate variability and land use changes on global biogenic volatile organic compound emissions. Atm. Chem. Phys. 6, 2129-2146 (2006).

95. Hewitt, C. N. et al. Nitrogen management is essential to prevent tropical oil palm plantations from causing ground-level ozone pollution. Proc. Natl Acad. Sci. USA 106, 18447-18451 (2009).

96. Soden, B. J. \& Held, I. M. An assessment of climate feedbacks in coupled ocean-atmosphere models. J. Climate 19, 3354-3360 (2006).
97. Shindell, D. T. et al. Multimodel projections of climate change from short-lived emissions due to human activities. J. Geophys. Res. 113, D11109 (2008).

98. Boucher, O. \& Reddy, M. S. Climate trade-off between black carbon and carbon dioxide. Energ. Policy 36, 193-200 (2008).

99. Betts, R. A. et al. Projected increase in continental runoff due to plant responses to increasing carbon dioxide. Nature 448, 1037-1041 (2007).

100. Collins, W. J., Derwent, R. G., Johnson, C. E. \& Stevenson, D. S. The oxidation of organic compounds in the troposphere and their global warming potentials. Clim. Change 52, 453-479 (2002).

\section{Acknowledgements}

The authors acknowledge the Integrated Land Ecosystem-Atmosphere Processes Study (iLEAPS), core project of the International Geosphere-Biosphere Programme (IGBP), and the discussions at the Science Workshop on Past, Present and Future Climate Change in Helsinki, November 2008. The Helsinki workshop and the manuscript preparation were supported by the Finnish Cultural Foundation. A.A. acknowledges support from the Academy of Finland, and the Swedish research councils VR and Formas. S.P.H. and S.Z. acknowledge funding from the EC-supported project GREENCYCLES (MRTNCT-2004-512464). K.T. was supported by an appointment to the NASA Postdoctoral Program at the Goddard Institute for Space Studies, administered by Oak Ridge Associated Universities through a contract with NASA. The work at Lawrence Berkeley National Laboratory was performed under Contract No. DE-AC02-05CH11231. S.M. acknowledges funding support from the NASA MAP program and the DOE ASR program. P.J.B. acknowledges support from the US NSF Paleoclimate program. Suggestions made by Chris Jones helped to improve our analysis substantially.

\section{Author contributions}

This Review was conceived at a workshop coordinated by M.K., A.K. and S.S., and all authors participated in the subsequent discussions and planning. S.M., K.T., S.Z., H.F., D.D. and G.S. contributed model simulations; A.A., S.P.H., P.J.B., S.S. and S.Z. were responsible for analyses and figures; and A.A. and S.P.H. were responsible for the first draft of the paper. All authors provided input to the drafting and final version of the manuscript.

\section{Additional information}

The authors declare no competing financial interests. 